\title{
TACitus On the Parthians
}

\author{
Edward Dąbrowa
}

Jagiellonian University in Kraków

\begin{abstract}
Tacitus is the only Roman historian who devoted his works to such an extent to Rome's eastern neighbor - the Parthian Empire. Scholars have researched the problem of Tacitus' attitude towards the Parthians on many occasions. It seems that what is the most important question is not Tacitus' opinion, but the perspective from which he looked at this topic combined with the source he used when describing the Parthians and their history. Another interesting question is also how deep Tacitus' knowledge was of the past of the Parthian Empire and the history of Roman-Parthian relations. The aim of this paper is to verify what Tacitus wrote about the Parthians throughout his works. Without taking into account all this evidence, it is not possible to propose a proper evaluation or balanced observations concerning his presentation of the Roman-Parthian relations and internal history, society and customs of the Arsacid state in the first century CE.
\end{abstract}

Key words: Tacitus, history of Parthia, Roman-Parthian relations.

Among the small number of Roman historians of the early imperial period whose works - to varying degrees - described Roman-Parthian relations, it was Publius Cornelius Tacitus ${ }^{1}$ who devoted a particularly large amount of space to this issue, as well as to the Parthians themselves. His presentation of the panorama of the succession of events from the death of Augustus to that of Domitian depicts the most important political events taking place in the Roman Empire and beyond its borders. The external events which interested him the most were those with a direct or indirect effect on Roman political interests. In the context of these interests, the lands to the east of the imperial borders were the subject of many political and diplomatic forays on the part of the Roman rulers as they sought to contain the most dangerous rival capable of hampering them in securing domination in the East - the Parthian state ruled by the Arsacid dynasty. The long and variable history of this rivalry explain why Tacitus occupied himself so much in his major historical works (Historiae and Annales) with the events playing out in Armenia, the Caucasus, and the Parthian state.

\footnotetext{
${ }^{1}$ PIR ${ }^{2}$ C 1467; Oliver 1977, 64-70; Birley 2000, 230-234.
} 
The first of these to be published was the Historiae, which Tacitus wrote over the first decade of the 2 nd century CE, during the rule of Emperor Trajan. ${ }^{2}$ Twelve volumes of this work probably existed, presenting the history of the Roman Empire in the years 69-96 CE; yet only the first four, and part of the fifth, survive. These books contain a description of the rivalry for rule in Rome of 69-70 CE, between Galba, Otho, Vitellius and Vespasian, while Tacitus' narrative consigns other, contemporaneous events to the background. Still, though, the books mention the Parthians a few times, ${ }^{3}$ so there is no reason to doubt that they also featured prominently in the lost volumes of the $\mathrm{Hi}$ storiae, if only because the rule of the Flavian dynasty was characterized by frequently tense relations between Rome and its eastern neighbor. ${ }^{4}$ These tensions were still less common, however, than during the rule of the Julio-Claudian dynasty. ${ }^{5}$

The Annales appeared several years later, during the rule of Emperor Hadrian. ${ }^{6}$ In this work, Tacitus presented the history of the reign of the rulers of the Julio-Claudian dynasty, from the death of Augustus to that of Nero. This work too is incomplete - only 12 books remain, in whole or in part, of the original 18 or $16 .^{7}$ There are numerous references to the Parthians in the Annales. One could go as far as to say that they are among the fundamental sources of knowledge on Roman-Parthian relations in the period from Tiberius to Nero. ${ }^{8}$ We should add that it was not just in his historical works that Tacitus wrote about the Parthians - he also mentioned them in the Germania $(17 ; 37)$, a treatise on the ethnography of the Germanic tribes.

The question of Tacitus' attitude towards the Parthians has already occupied many scholars who are particularly interested in the issue of his perception and assessment of them. ${ }^{9}$ I would argue, however, that what is important is not just what Tacitus thought of the Parthians, but above all what he knew about them and about Roman-Parthian relations, and which sources he used. By reflecting on these questions, we will not seek to interpret his work from the point of view of our current knowledge on the events that he describes. This requires a review - in chronological order - of Tacitus' information about the domestic situation in the Parthian state as well as its rulers' external political activity, and in particular of the elements of his narrative that refer to the Parthian rivalry with Rome over Armenia and the mutual relations between these states. We shall begin this review with the information contained in the Annales.

2 Cf. Syme 1958, 117-120; Birley 2000, 241.

${ }^{3}$ See Hist. 1,2,1; 82,3; 4,51,1-2; cf. also 5,8,2-3; 9,1.

${ }^{4}$ Cf. Debevoise 1938, 201-202; Dąbrowa 1981; 1994.

${ }^{5}$ See Syme 1958, 211-216.

${ }^{6}$ On the time when the Annales was written, see Syme 1958, 467-474; Potter 1991, 287-290; Birley 2000, 242-246.

${ }^{7}$ Cf. Syme 1958, 263-266.

${ }^{8}$ We also have the account of Josephus on this period given in his Antiquitates, which is to an extent parallel, albeit not as detailed, and written from a different perspective: Rajak 1998, 312-323.

${ }^{9}$ Walser 1951, 136-154; Ehrhardt 1998, 302-304. 


\section{Vonones, Artabanus and Roman-Parthian relations in the first years of the rule of Tiberius}

Issues related to Parthia were first raised by Tacitus in relation to the matter of Vonones, son of the king of Parthia, Phraates IV (Ann. 2,1,1-4,3). ${ }^{10}$ He found himself in Rome, along with other members of Phraates IV's family, when the latter placed them in the custody of Emperor Augustus. ${ }^{11}$ This decision was enforced by the internal situation in the royal family, torn apart by the struggle for succession between Phraates IV's sons from various marriages. Queen Thea Musa, the last of several royal wives, had gained an influential position in the Parthian court, which allowed her to secure the throne for her and Phraates IV's son Phraataces (Phraates V). ${ }^{12}$ The king, with serious concerns for the fate of his other sons, ${ }^{13}$ thus asked Augustus to provide refuge and care for them in Rome. This step was later exploited many times in Roman propaganda to emphasize Rome's supremacy over its eastern neighbor. However, Tacitus himself makes it clear that Phraates IV's decision was enforced by the domestic situation in his state, and not by pressure from Rome (Ann. 2,1,2). ${ }^{14}$ Following the death of Phraates IV, and with the continued dynastic struggles, some of the Parthian aristocrats asked Augustus to send Vonones, the eldest of the royal sons staying in Rome, to Parthia. Augustus acceded to this request, and also offered the support necessary for this trip to succeed (Ann. 2,2,1). Yet Vonones' rule proved short-lived. Having been raised in Rome, he was unfamiliar with the national traditions to which his Parthian subjects were attached. His lack of respect for these traditions, coupled with his style of governance, soon turned certain members of the Parthian elites against him, and they invited Artabanus (II), ${ }^{15}$ from a secondary line of Arsacids, to the throne (Ann. 2,2,1; 3,1). The resultant confrontation between the pretenders to the throne ended in the defeat of Vonones. He fled Parthia and found refuge in Armenia, where, at a difficult moment for the country, he secured power (Ann. 2,3,1; 4,2). ${ }^{16}$ This turn of events did not suit the interests of the Romans, as Vonones' presence in Armenia meant the threat of conflict with Artabanus, which Tiberius, then ruler of Rome, was keen to avoid (Ann. 2,4,3).

The cited passages from the Annales shows that Tacitus had a good grasp of the complicated domestic situation in the Parthian Empire and Armenia in the first years of Tiberius' rule. Equally importantly, he was aware of the considerable influence that events in the East had on the shape of Roman policy in this region as well as Rome's internal affairs. ${ }^{17}$ We can only guess, as nowhere does Tacitus confirm it himself, that he

10 PIR V 994; Karras-Klapproth 1988, 210-213.

11 Strabo 16,1,28 (748); Res Gestae Divi Augusti 32; cf. Josephus, AJ 18,39-42. For much more about this episode, see Pani 1972, 26-35; Dąbrowa 1983, 65-66, note 213; Dąbrowa 1987, 63-71; Nierdegaard 1988, 102115; Strugnell 2008, 283-285; Scardigli 2009, 131, 132-134.

12 PIR P 394; Karras-Klapproth 1988, 145-147.

13 Cf. Josephus, $A J 18,40-41$.

14 Yet this does not stop Tacitus in another place from speaking of the offspring of Phraates IV as hostages; cf. Ann. 11,10,4 (see Malloch 2013, 172-173); 12,10,1. Other Roman authors do likewise: Vell. Paterculus 2,94,4; Strabo 6,4,2 (288); Josephus, AJ 18,42; Suet., Aug. 21,3; 43,4; Justin 42,5,12.

15 PIR A 1155; Karras-Klapproth 1988, 28-34.

${ }^{16}$ Cf. SC de Cn. Pisone patre, ll. 39-45; Josephus, AJ 18, 50.

17 Cf. Eck - Caballos - Fernández 1996, 107. 
made use of Res Gestae Divi Augusti, the works of Strabo and Pompey Trogus, which present Parthian-Roman relations at the time of Augustus. We find allusions to these in many places in his work. Yet it is unlikely that he used the work of Velleius Paterculus, as no elements of this historian's work are reflected in Tacitus' account.

\section{Germanicus' mission to the East (18 CE) and Artabanus II}

The next focus of Tacitus' attention was the mission to the East of Germanicus, dispatched by Tiberius in $18 \mathrm{CE}$. According to Tacitus, this mission had two political objectives. One of these was closely related to the question of succession in Rome, while the other concerned the shape of Rome's relations with the Parthians. ${ }^{18}$ The most important task given to Germanicus by Tiberius was to sort out the political situation in Armenia, which remained without a leader after Vonones' deposition from the throne (Ann. 2,55,6). There is no doubt that this was a very significant task, as both the Roman and the Parthian empires were extremely keen to control Armenia owing to its strategic location between the two states. Artabanus' preoccupation with the struggle for leadership of Parthia made it easier for Germanicus to realize his plans. Without great difficulty, he placed Artaxias on the throne of Armenia. ${ }^{19}$ Despite hailing from Pontus, the new king was popular among the Armenians and also accepted by the Parthians (Ann. 2,56,2-3). ${ }^{20}$ This decision led to many years of stability in the political situation of Armenia.

Germanicus' presence in the East persuaded Artabanus to forge closer contacts with him. His envoys visited Germanicus, invoking the friendship treaties between the two states $^{21}$ and declaring the Parthian king's readiness to renew them and meet with the Roman commander in person (Ann. 2,58,1). Germanicus exercised caution regarding renewal or deepening of bilateral relations, but did not refuse a meeting with the Parthian king (Ann. 2,58,2). One of the important topics raised was the future of Vonones, who was staying in Syria. Artabanus asked Germanicus to have him removed from the territory, arguing that he attracted people who could bring about unrest. What he probably had in mind was that Vonones' presence in Syria made him a leader of the hostile opposition. Although Germanicus did not respond directly to this request, Artabanus attained his goal indirectly. Vonones' actions in Armenia were supported by the then

18 Elsewhere, Tacitus makes it clear that the unstable political situation in Armenia and the Parthian state suited Tiberius, as, by sending Germanicus to the East to safeguard Roman interests, he ridded Rome of an extremely popular potential rival (Ann. 2,5,1; 2,43,1-2); cf. Pani 1993, 235-255.

19 Cf. RPC I, no. 3629-3630.

${ }^{20} P I R^{2}$ A 1168 . He was originally called Zenon, and was one of two sons of King Polemon of Pontus (PIR2 P 531): Strabo 12,3,29 (C 556). Cf. Pani 1972, 188-191. We know a couple of the Zenon's coins related probably to his enthronement in Armenia, see Krengel 2013, 59-73; Kovacs 2014, 19-25; 2016, 31-32.

21 Artabanus was most certainly referring to a Roman-Parthian agreement from the time of Augustus. We do not know which one, as the emperor in fact concluded two such agreements: one with Phraates IV (Res Gestae Divi Augusti 29), and the other with his son Phraataces (Dio Cassius 55,10a,4). The differing political context of these agreements appears to make it likely that the Parthian ruler may have been invoking the first one; cf. Dąbrowa 1983, 41-42, 43-44. See also Wheeler 2002, 287-291. According to S. Malloch (2013, 123), Tac. Ann. 2,58 refers to the foedus of CE 1 with Gaius Caesar. 
governor of Syria, Piso, with whom Germanicus was in conflict. ${ }^{22}$ As a result, the imperial envoy ordered that Vonones be sent to Pompeiopolis, in the province of Cilicia adjacent to Syria.

The passage from the Annales on Germanicus' mission contains rather few details concerning Parthian issues. In it, though, Tacitus shows the influence the changing political situation in Armenia and Germanicus' appearance had on Artabanus' approach. We do not know of any direct actions planned against the Parthians by the Roman emissary. ${ }^{23}$ Yet there is no doubt that his very presence at the border of the Arsacid state might have been of such concern to the Parthian ruler that he set about persuading Germanicus of his friendship towards Rome, and at all cost preventing him from supporting the enemies of the Parthians.

\section{Artabanus II's intervention in Armenia (34 CE) and Tiberius' reaction to it}

The events in the East, among which those concerning the Parthians occupy a significant place, feature prominently in the sixth book, in the part on the years 35-36 CE (Ann. 6,31,1-37,4; 41,2-44,5). These events were of great importance for Rome's eastern policy, and the Parthians played a major role in them, both directly and indirectly. According to Tacitus, the beginning of this series of events came in $35 \mathrm{CE}$, when a secret delegation of the Parthian aristocracy opposed to Artabanus' rule arrived in Rome. ${ }^{24}$ The envoys asked Tiberius to send Phraates, ${ }^{25}$ the next son of Phraates IV, to Parthia to take the Arsacid throne. They argued that Rome's support for Phraates, along with his appearance in the Parthian state, were crucial in the effort to mobilize the opponents of Artabanus (Ann. 6,31,1-2). The words of Tacitus himself suggest that, after a lengthy period of comparative peace, ${ }^{26}$ the relations of Rome with the Parthian state worsened considerably at this point. The reason for this was the military successes enjoyed by Artabanus, which allowed him to gain supremacy over the domestic opposition and pursue a more determined foreign policy, including towards those lands in which the Romans had a keen interest. Armenia was among the more important of these. Its ruler, Artaxias, died in $34 \mathrm{CE}$, and Artabanus took immediate advantage of this event by inserting his son Arsaces on the throne (Ann. 6,31,1). ${ }^{27}$ Buoyed by this and other successes, he demanded of Tiberius that he give up the riches of Vonones, which were in Roman hands, and laid his claims to areas that had once been part of the Achaemenid Empire and the Alexander's and the Seleucids'

${ }^{22}$ Cf. SC de Cn. Pisone patre, ll. 37-45; Eck - Caballos - Fernández 1996, 163-165.

${ }^{23}$ Cf. Pani 1993, 241-244.

${ }^{24}$ For more on this delegation, as well as later ones, see Dąbrowa 1989; 2002; 2013, 58-59.

${ }^{25}$ PIR 2 396; Karras-Klapproth 1988, 147-148.

${ }^{26}$ The fourth book of Annales ends with the events of $28 \mathrm{CE}$. Although the sixth book begins with the events of $31 \mathrm{CE}$, the first references to the Parthians are made only in the context of the events of 35 CE. We might suppose, on this basis, that the relations between the two states in these years were largely tension-free.

${ }^{27}$ Karras-Klapproth 1988, 25-26. 
Empire and were now in the borders of Roman Empire. ${ }^{28}$ These demands, as well as he way in which they were expressed, were received badly in Rome. Although a situation unfavorable to Roman interests had developed in the East, Tiberius temporarily delayed making any actions. He was reluctant to involve Roman forces directly in local conflict, and at the same time ready to use them to his own advantage through the local rulers. An opportunity to take action against Artabanus arrived with the aforementioned delegation of Parthian aristocrats. Not only was he happy to satisfy their request, but he also equipped the pretender to the Arsacid throne with everything that might guarantee the success of his expedition. Yet Roman support for Phraates did not include military aid in Parthian territory, ${ }^{29}$ and his death from illness shortly after entering Parthian lands once and for all dashed the hopes invested in him. Upon receiving word of Phraates' expedition, Artabanus disposed of the opposition leaders who had instigated it (Ann. 6,31,2; 32,1-2).

Tiberius was doubtless aware of the perils caused to Roman interests by the excessively energetic Artabanus. Phraates' death did not dissuade him from realizing the plans he had attached to this expedition. This was what led him, on his own initiative, to send to Parthia another representative of the Arsacid dynasty who was in Rome at the time, Tiridates. The goal of this expedition was to occupy Artabanus' forces sufficiently to prevent him from coming to the aid of Arsaces, the king of Armenia, which was about to come under attack from the ruler of Iberia, Mithridates, egged on by the Romans (Ann. 6,32,3). ${ }^{30}$ Recruiting Mithridates to fight for Armenia was a major success of Roman diplomacy. Tiberius took advantage of the circumstance that the rulers of Iberia had long been interested in Armenia, but owing to the Roman-Parthian rivalry over it had not been able to secure success there. A further factor that Tiberius was able to make use of in achieving his aims was Mithridates' rivalry with his brother Pharasmenes ${ }^{31}$ over rule in Iberia. The emperor entrusted the then governor of Syria, Lucius Vitellius, to realize this complex political plan.

Tacitus makes it clear that the two parts of Tiberius' strategic plan were not put into practice at the same time. The first arena of battle was Armenia (Ann. 6,33,1), which Mithridates succeeded in taking control of. ${ }^{32}$ Artabanus, learning of the Iberian attack, dispatched succor with another son, Orodes. ${ }^{33}$ Yet his actions did not have the intended effect, as thanks to the political activity of Pharasmenes, who actively supported Mithridates, Orodes neither managed to gather sufficient forces among allies, nor to overcome the Caucasus passes through which the road to Armenia led. His campaign ultimately finished in failure owing to the defeat at the hands of Pharasmanes (Ann. 6,33,1-35,2).

${ }_{28}$ Ann. 6,31,1: addita contumelia et missis, qui gazam a Vononem relictam in Syria Ciliciaque reposcerent; simul veteres Persarum ac Macedonum terminos, seque invasurum possessa Cyro et post Alexandro vaniloquentiam ac minas iaciebat. These claims constituted part of Artabanus' political programme: Wolski 1966, 72-73; 1991, 53; 1993, 154-155. Cf. Shayegan 2017, 433-436.

${ }^{29}$ Ann. 6,32,1: Cupitum id Tiberio: ornat Phraaten accingitque paternum ad fastigium, destinata retinens, consiliis et astu res externas moliri, arma procul habere.

$30 P^{2} \mathrm{M} 644$.

31 PIR 2341.

32 Tacitus does not state directly that he acquired the throne of Armenia, but his reference elsewhere means that we can assume this to have been the case; cf. Ann. 11,8,1.

33 PIR ${ }^{2}$ O 152; Karras-Klapproth 1988, 110-111. 
Receiving news of this, Artabanus decided to go to Orodes' aid, but at this point Vitellius joined the fray. His feigned preparations for an incursion into Mesopotamia led Artabanus to abandon the Armenian expedition - according to Tacitus, because he was keen to avoid war with Rome (Ann. 6,36,1). Vitellius' continuation of the diversionary actions aimed against Artabanus was successful (Ann. 6,36,2): the loss of social support meant that the Parthian monarch was forced to seek refuge and support among the Asiatic peoples of the provinces of his state (Ann. 6,36,2-4).

The chronology of events presented by Tacitus suggests that only after Artabanus' withdrawal did Tiridates, ${ }^{34}$ with support up to the border of the Roman Empire from Vitellius' troops, begin the advance for the Arsacid crown (Ann. 6,37,1; 37,4). At first enthusiastically received, his rule rather soon began to encounter a negative response from the aristocracy. Among the causes of the divisions that opened up were competition for influence with the new ruler, as well as a negative assessment of him from many members of this group. They brought about the restoration of the throne to Artabanus (Ann. 6,43,1-3), whose decisive actions against Tiridates' supporters resulted in victory. Isolated, Tiridates left Mesopotamia and returned to Syria (Ann. 6,44,5).

Tacitus' account of Tiberius' support for the Parthian pretenders in the struggle with Artabanus and his diplomatic dealings over Armenia is characterized by a startling array of diverse details not provided by any other Roman historians. These concern both the internal situation in the Arsacid state and the whole picture of the battles waged in Armenia and the Caucasus. Furthermore, Tacitus paints a complete picture of Tiberius' sophisticated diplomatic maneuvers designed to achieve beneficial results for the Romans. These demonstrate that at the time in the capital of the Roman Empire people had extensive knowledge of the political situation in various regions of the East. Unfortunately, at no point in his work does Tacitus mention the sources which he used.

\section{Gotarzes' conflict with Vardanes}

In his account of the events of $47 \mathrm{CE}$, Tacitus presents the course of the struggle for power between Gotarzes ${ }^{35}$ and Vardanes at length (Ann. 11,8,1-10,4), ${ }^{36}$ at the same time showing the activities of Roman diplomacy, as it strove to handle the internal Parthian conflict in a way that it would be of most benefit to Rome. The conflict between the two pretenders to the Arsacid throne was hugely significant for the configuration of the political situation in leaderless Armenia. No doubt mindful of this danger, Emperor Claudius handed the country's throne back to Mithridates of Iberia, a previous occupant of the throne under Tiberius who had been removed from it by Gaius (Caligula) (Ann. 11,8,1), and who was in Rome at the time. The complications of the situation in the Arsacid state were known in Rome from the letters of Pharasmanes, ruler of Iberia and brother of Mithridates, to the Roman emperor, or Tacitus

\footnotetext{
$34 P I R^{2}$ T 237; Karras-Klapproth 1988, 176-178.

35 PIR² G 195; Karras-Klapproth 1988, 60-64.

${ }^{36} P I R^{2}$ V 259; Karras-Klapproth 1988, 186-189.
} 
read it in his narrative sources, who also knew about the 'secret' delegation. ${ }^{37}$ The Roman historian's work is all the more valuable owing to the lack of narrative sources of Parthian origin. It refers to the circumstances of the violent death of Artabanus, the son of Artabanus of the same name and his family, at the hands of his brother Gotarzes, as well as the further political consequences of this act $(A n n .11,8,2) .{ }^{38}$ The mobilization of the supporters of the murdered monarch under the command of Vardanes caused Gotarzes to lose control over a significant part of the state - and some time later, after his rival's forces had grown stronger, on the rest of his dominion. The only point of resistance against Vardanes' rule remained the strongly fortified Seleucia on the Tigris. The lengthy siege of the city allowed Gotarzes to take the initiative, managing to gather new forces and renew the struggle with his rival. Vardanes was forced to seek refuge as far away as Bactria (Ann. 11,8,2-4). At the same time, Mithridates, backed by Rome, succeeded in taking control of Armenia, although before he arrived the Armenian aristocrats tried to find another candidate for monarch (Ann. 11,9,1-2). This situation changed when Gotarzes and Vardanes unexpectedly signed an agreement that led to a division of their spheres of influence being determined. The Arsacid crown went to Vardanes, allowing him to quickly stabilize the political situation in the western provinces of his dominion; Seleucia too accepted his suzerainty (Ann. 11,9,3-4). Buoyed by these successes, he set about preparing to regain control of Armenia, but his plans were dashed by threats of war from the Syrian governor Vibius Marsus, as well as Gotarzes, who broke off their agreement (Ann. 11,10,1). For Vardanes, more important than Armenia was the need to deal with the internal enemy. Victory over Gotarzes had emboldened him to the extent that some of the aristocrats, fearing for their own positions, ordered his assassination. Yet Vardanes' death did not soothe the situation in the Parthian state. Certain aristocrats wanted to bring in Meherdates, grandson of Phraates IV, ${ }^{39}$ from Rome, while the majority were in favor of handing power back to Gotarzes. However, his ruling style and extravagance soon turned the Parthians against him, and they sent a secret delegation to Claudius requesting that Meherdates be sent (Ann. 11,10,4).

\section{Meherdates' expedition}

Tacitus presents the course of this delegation and the events that followed it in detail in the twelfth book of Annales (12,10,1-14,3), which describes the events of $49 \mathrm{CE}$. Upon arrival in Rome, the Parthian emissaries presented their request for Meherdates to be sent. By way of justification, their arguments included the suggestion that the arrival of the Parthian prince, a member of the Arsacid dynasty, would prevent Gotarzes' autocratic rule from being further strengthened - this had already led to the deaths of his closest family members and become onerous for all groups of subjects. The emissaries

${ }^{37}$ Ann. 11,8,1: ... rex Hiberis idemque Mithridatis frater nuntiabat discordare Parthos summaque Imperii ambigua, minora sine cura haberi.

38 Malloch 2013, 127-130.

39 PIR 2 M 443; Karras-Klapproth 1988, 73-74. 
presented it as the emperor's duty to react favorably to their request, given the friendly relations between the Parthian state and Rome. ${ }^{40}$

Claudius agreed to Meherdates' expedition, entrusting the task of supporting him to Gaius Cassius, the governor of Syria. Cassius took the pretender to the Arsacid throne to Zeugma on the Euphrates, where he was met by Parthian aristocrats and troops of the allied rulers, which were to give him military support in Parthian territory (Ann. 12,12,2-3). Upon parting from Meherdates on the banks of the Euphrates, the Syrian governor advised him to act quickly in order to give himself the best chance of success. Yet his advance was to encounter a series of difficulties resulting from various circumstances: choosing the wrong road, betrayal of an ally and the wavering political stances of the Parthian aristocrats, many of whom, despite their declared support for Meherdates, remained supporters of Gotarzes. Gotarzes was in no hurry to encounter Meherdates directly, as he first need to gather adequate forces, but he carried out a succession of diversion tactics in his opponent's camp. This proved so successful that many of Meherdates' allies withdrew. The result was that Meherdates lost the battle that decided on the fate of his expedition. Soon, betrayed by a man from his close circles, he found himself in Gotarzes' hands. Although the victor spared him his life, he mutilated him permanently, thus removing him for good from the rivalry for the Parthian throne (Ann. 12,12,3-14,3).

Tacitus brings the history of Meherdates' expedition to a close with information about Gotarzes' natural death (51 CE), about his successor Vonones (II) (51 CE) $)^{41}$ - whose rule he did not see as worthy of much note - and about Vologases' taking the throne after him (51-c. 79/80 CE) (Ann. 12,14,4). ${ }^{42}$ According to this account, in 49-51 CE, despite Rome's engagement on the side of Meherdates, relations between the two states did not visibly worsen.

Tacitus refers to many details in his account of the two aforementioned episodes; we have mentioned only the few most important ones. The most interesting of these include those referring to incidents that took place in Parthia. The historian's excellent understanding of the domestic situation of the Arsacid state and knowledge of the names of the protagonists and their political positions show that he must have gained this knowledge from sources containing detailed and credible information, probably from some narrative source(s) unknown to us or from documents kept at archives.

\section{Radamistus, ruler of Armenia, and the Parthian-Iberian rivalry over Armenia}

On the subject of $51 \mathrm{CE}$, Tacitus devotes much space to the events in Armenia, which exerted a major influence on the course of Roman-Parthian relations (Ann. 12,43,1). Initially, these events were of a purely local nature. Yet this changed radically when

40 The political arguments used to justify Meherdates' candidacy are worth quoting: Ann. 12,10,2: veterem sibi ac publice coeptam nobiscum amicitiam, et subveniendum sociis virium aemulis cedentibusque per reverentiam. Ideo regum liberos obsides dari, ut, si domestici imperii taedeat, sit regressus ad principem patresque, quorum moribus adsuefactus rex melior adscisceretur.

${ }^{41} P I R^{2}$ V 995; Karras-Klapproth 1988, 214-215.

${ }^{42}$ PIR ${ }^{2}$ V 940; Karras-Klapproth 1988, 192-198. 
the Parthian king Vologases became involved. Rome could not fail to react to his intervention, with the result that its relations with the Parthians worsened sharply and many years of armed conflict ensued.

What proved to be a fateful event was the attempt by Pharasmanes, ruler of Caucasian Iberia, to conquer Armenia, and place his son Radamistus on the throne. ${ }^{43}$ The ruler of Armenia at the time was Mithridates, the brother of Pharasmanes, to whose support he owed his position. Fearful of Radamistus' growing ambitions, Pharasmanes pushed him into action against his uncle, providing him with the support of substantial forces. Their rapid attack forced Mithridates to flee and take refuge in the Gorneae fortress, occupied by a Roman garrison. Radamistus bribed the Romans, allowing him to coax Mithridates into going outside the walls, on the pretense of commencing peace negotiations. Yet instead he was captured treacherously, and murdered along with his closest family members (Ann. 12,47,1-48, 5). Upon receiving news of what had happened in Armenia, the governor of Syria, C. Ummidius Durmius Quadratus, demanded of Pharasmanes that his son and the Iberian forces supporting him leave Armenia (Ann. 12,48,1-3), but this decision proved hard to enforce. The procurator of Cappadocia, who was supposed to supervise it, was bribed by Radamistus, and instead of preventing him, he urged him to don his monarchical insignia (Ann. 12,49,1). The next attempt to remove Radamistus, made by the legate of one of the Syrian legions, was abandoned, for fear that the legion's incursion into Armenian territory might trigger war with the Parthians (Ann. 12,49,2).

This concern was not unfounded: Vologases decided to exploit the unstable situation in Armenia to regain his former influence, with the intention of putting a representative of the Arsacid dynasty, his brother Tiridates, on the throne (Ann. 12,50,1). ${ }^{44}$ His expedition brought short-lived success, yet a set of unfavorable factors forced him to withdraw, and Radamistus once again occupied the capital of Armenia (Ann. 12,50,2). However, the rebellion of the Armenian population against his government forced him to flee and take refuge in Iberia in his father's court (Ann. 12,50,2-51,2).

Tacitus' account of the events in Armenia is full of details whose sources are unknown to us, as is the case of many other events that he describes that took place in this country and the Parthian state. We can assume, though, that he might have known at least some of them from documents on the activity in the East and Syria functionaries of the Roman provincial administration. In his personal assessments of the events he describes, Tacitus is unequivocally negative regarding the conduct of the representatives of the Roman authorities, stating that their corruption, ineptitude, indecision, and even reluctance to act were frequently at odds with Roman interests in this field.

\section{The Roman-Parthian rivalry over Armenia during Nero's rule}

Tacitus included the next part of his account of the situation in Armenia and RomeParthia relations in the thirteenth book, in the part on the year 54 CE (Ann. 13,6,1-9,3), although he frequently went beyond this chronological framework in order to depict events in their full historical context (Ann. 13,9,3).

\footnotetext{
$43 P I R^{2} \mathrm{R} 7$.

$44 P I R^{2}$ T 238; Karras-Klapproth 1988, 179-184.
} 
The historian begins this narrative from events in Armenia, invaded by the Parthians as they drove Radamistus out (Ann. 13,6,1). This probably took place in Claudius' lifetime, since the information about these events reached Rome in late $54 \mathrm{CE}$, by which time Nero was in power (Ann. 13,6,2-3). The emperor's reaction to this news was to concentrate legions close to the borders of Armenia, instruct the rulers of Commagene and Judea to be ready to attack the Parthian territory, and put new rulers on the throne of Armenia Minor and Sophene, no doubt with the intention of having them collaborate with the Romans. ${ }^{45}$ Yet confrontation with Vologases did not come to pass, as he, faced with the appearance of a pretender to the Parthian throne in the form of his own son, Vardanes, ${ }^{46}$ withdrew his forces from Armenia (Ann. 13,7,2). The task of maintaining Roman control over Armenia fell to Cn. Domitius Corbulo, who was handed command over troops stationed in Cappadocia, part of the Syrian army, and placed in charge of vassal rulers; the governor of Syria was presented with two legions (Ann. 13,8,1-3). This situation became the source of rivalry and conflicts between the two. They each separately demanded that Vologases cease military operations and demonstrate appropriate respect to Rome by handing over hostages (Ann. 13,9,1). Vologases acceded to these demands, thus easing the situation in the borderlands of Armenia, the Parthian state and the Roman Empire for some time. Yet this certainly does not mean that the Parthian ruler abandoned his plan to restore the throne of Armenia to Tiridates. ${ }^{47}$

Vologases' next attempt to realize his Armenian plans came in $58 \mathrm{CE}$. This approach was motivated by a section of the Armenian population, who tended to favor the Parthians on account of numerous cultural and social similarities as well as family links (Ann. 13,34,2). When Tiridates encroached into Armenia, Vologases offered him support. The main regions to come under attack were those whose population sympathized with Rome. The speed of the actions, and avoidance of open confrontation, made it hard for both the Armenians themselves and Corbulo to stop Tiridates. Events took a favorable turn for the Romans when they were joined in the fighting in Armenia by Pharasmanes of Iberia and the Moschi (Ann. 13,37,1-3).

Tiridates thus sent envoys to Corbulo to present the arguments in favor of his right to the throne of Armenia, which encompassed both the fact that he had previously held power there and Vologases' goodwill in maintaining friendly relations with Rome. He also made it clear that he preferred the diplomatic approach, but that the Parthians would not hesitate to go to war, should the need arise (Ann. 13,37,4). The Roman commander was well aware that Vologases was unlikely to deliver on his threat of war, caught up as he was with domestic problems with the situation in Hyrcania. He therefore suggested that Tiridates go directly to the emperor, but abandon the idea of military action, in order to create a hope of an amicable settlement to the dispute (Ann. 13,37,5). Since the negotiations carried out by the emissaries failed to secure peace, a meeting between Tiridates and Corbulo was agreed (Ann. 13,38,1). Yet Tiridates' fear of falling into a Ro-

45 These events took place not before around mid-55 CE. We should also take into account the time needed to deliver orders from Rome to all addressees and for the preparations necessary for executing them.

46 PIR V 260; Karras-Klapproth 1988, 189-190.

${ }^{47}$ According to Tacitus (Ann. 13,9,1), Vologases reaped benefits from handing the hostages over: he was still able to prepare for war and dispose of his rivals: ... Vologaeses, quo bellum ex commodo pararet, an ut aemulationis suspectos per nomen obsidum amoveret, tradit nobilissiomos ex familia Arsacidarum. 
man trap prevented this from coming to pass (Ann. 13,38,4-39,1). Corbulo then went on the offensive against all points of resistance of the supporters of Tiridates' rule. Apart from the fortresses they held, this also targeted Artaxata, the Armenian capital (Ann. 13,39,2-6). To prevent its capture, Tiridates attacked a column of Roman troops, but, prepared for this eventuality, they managed to contain him. Tiridates withdrew, and Corbulo, expecting him to take refuge in Artaxata, set off in that direction with a section of his units and captured the city without a struggle (Ann. 13, 40,1-41,4). Yet he did not content himself with this success.

Tacitus describes the further events of 59-60 CE in the fourteenth book of Annales. After levelling Artaxata, we learn, Corbulo set off for Tigranocerta, destroying the pockets of resistance he encountered on the way (Ann. 14,23,1-25,1). Realizing his plans was made easier by the fact that the Hyrcanians had successfully engaged Vologases' forces, meaning that he was unable to come to his brother's aid. Tiridates endeavored to continue the fight, but after meeting Roman troops on the way he abandoned attempts to enter Armenia (Ann. 14,26,1). The situation there took a turn for the worse for him and the pro-Parthian alliance: Corbulo pacified the country and placed Tigranes on the throne there, on the instructions of Nero himself. ${ }^{48}$ To consolidate his power, the Romans not only offered the protection of a garrison, but also placed under the control of vassal rulers the parts of Armenia that bordered with their territory (Ann. 14,26,1-2).

This state of affairs probably continued until $62 \mathrm{CE}$, as Tacitus returns to the question of Armenia and Roman-Parthian relations in the fifteenth book, which portrays the events of 62-65 CE. Right up till the latter year, Vologases, absorbed in the internal affairs of his state, was unable to defend his brother's interests. Only news of Tigranes' aggressive actions towards the Adiabene kingdom, whose rulers accepted the suzerainty of the Arsacids, persuaded him to change his position (Ann. 15,1,1-3). Any further inactivity on Vologases' part would have threatened his interests and hit the dynasty's prestige and its ruler's authority. ${ }^{49} \mathrm{He}$ blamed the Romans for the outbreak of armed conflict, placing himself in the role of protector of the endangered legacy of his ancestors, including Armenia. During a public feast, the king of Parthia supported his brother's demands, placing the royal diadem on his head and handing him a select equestrian unit along with Adiabenian reinforcements to support him in the struggle to regain Armenia. Upon completion of the conflict with the Hyrcanians, he readied himself for an attack on Roman territory (Ann. 15,2,1-4).

These plans persuaded Corbulo to begin preparations for defending Syria, fearing that this would be the target of an attack from Vologases (Ann. 15,3,1-2). Upon receiving news of the unexpected, but unsuccessful campaign of Tiridates' army, launched with the aim of regaining Armenia (Ann. 15,4,1-3), Corbulo sent a delegation to Vologases, demanding that he cease the offensive against Tigranes, as the Romans would attack Parthian territory in revenge. Owing to the difficult general strategic situation of the Arsacids in both Armenia and their own state, Vologases decided to commence negotiations in the matter of the crown for Tiridates with Nero himself. He withdrew his army from

$48 P^{2}$ T 207.

49 Cf. Ann. 15,1,4: non enim ignavia magna imperia contineri; virorum armorumque faciendum certamen; id in summa fortuna aequius quo validius, et sua retinere privatae domus, de alienis certare regiam laudam esse. 
Tigranocerta (Ann. 15,5,1-4), from which, some time later, the Roman units defending it also departed (cf. Ann. 15,6,2). In Rome, Corbulo's actions were regarded as a great success, although there was also speculation as to what had caused the Romans to leave Tigranocerta (Ann. 15,6,1).

The Parthian delegation returned from Rome empty-handed, leaving Vologases with no option but to renew military action (Ann. 15,7,1). The account of the military options from this war is too extensive and detailed to analyze here. ${ }^{50}$ One important episode from this conflict is worthy of attention, however: the Parthian king's siege of the Roman commander Caesennius Paetus in Rhandeia. This culminated in the capitulation of the Roman troops defending the fortress, and a peace accord that foresaw the Romans' complete withdrawal from Armenia and the possibility of Vologases sending a further delegation to Nero (Ann. 15,14,3; 16,2). The Parthian king exploited this situation for propaganda purposes, to demonstrate his power $(A n n .15,15,1-3) .{ }^{51}$ He also reached an agreement with Corbulo in the matter of the execution of the resolutions of the treaty with Paetus. This resulted in the withdrawal of Roman troops to behind the Euphrates, in return for the Parthians' retreat from Armenia (Ann. 15,17,3).

The struggle for Armenia came to a head in spring 63 CE. Vologases' delegation that had been sent to Rome demanded acknowledgement of Tiridates' rights to Armenia. They declared Tiridates' readiness to accept the diadem from the emperor, although for religious reasons he was unable to come to Rome in person. Vologases' suggestion was that the ceremony conferring rule of Armenia on Tiridates should take place before the legions (Ann. 15,24,1-2). Surprised by these demands, Nero, whom Paetus had not informed of the Romans' true situation in Armenia, despite learning of the defeat, intended to continue the war (Ann. 15,25,1-2). The Parthian envoys, dispatched without a response, but with gifts, left Rome convinced that if Tiridates approached the emperor in person, his request would be heard (Ann. 15,25,3). On Nero's command, Corbulo renewed military operations and entered Armenia. There, he encountered the emissaries of Tiridates and Vologases, arriving for peace talks (Ann. 15,27,1). Corbulo entered negotiations, hoping to bargain the best possible conditions for Rome. He argued that the Romans were in a much better position as they were only engaged in one conflict, whereas Vologases was dealing with constant domestic problems (Ann. 15,27,2). ${ }^{52}$ The most important moment in these talks was the meeting of Corbulo with Tiridates. The latter demanded this, suggesting that it take place in the place where Paetus had sur-

50 The course of this war has been the subject of numerous analyses and interpretations; cf. Debevoise 1938, 179-202; Heil 1997, 27-141.

51 The initial conditions of the negotiations dictated by Volgases served to demonstrate the Parthian superiority over the besieged Roman forces - Vologases, Pacorus and Tiridates participated in them (Ann. 15,14,1: Ad ea Vologaeses nihil pro causa, sed opperiendos sibi fratres Pacorum ac Tiridaten rescripsit; illum locum tempusque consilio destinatum, quid de Armenia cernerent; adiecisse deos dignum Arsacidarum, simul ut de legionibus Romanis statuerent.). It was also helped by the negotiation of the conditions of surrender not in the presence of the king, but through the mediation of a dignitary (Ann. 15,14,2: missi posthac Paeto nuntii et regis colloquium petitum, qui Vasacen praefectus equitatus ire iussit.).

52 This statement contains a clear allusion to the problems that the Parthian ruler had previously had in Hyrcania (Ann. 13,37,5; 14,25,2; 15,1,1; cf. Dąbrowa 1984, 141-147), as well as the current difficulties that were forcing him to stay in Ecbatana, making his participation in the negotiations impossible (cf. Ann. $15,31,1)$ 
rendered. Aware as he was of the significance of this choice for propaganda use, Corbulo assented to it (Ann. 15,28,1-3).

During this meeting, it was decided that Tiridates would take off his royal diadem before an image of Nero in the presence of Roman units, and would go to collect it from the emperor directly (Ann. 15,29,1). The diadem removal ceremony took place several days later, and, owing to the delay in his departure for Rome, Tiridates gave Corbulo his daughter as a hostage and handed him an official letter to the emperor (Ann. 15,30,2). Vologases too accepted this solution. But he also asked Corbulo to ensure that Tiridates was treated with the honors due to a member of the Arsacid family during his journey to Rome (Ann. 15,31).

With the information about the content of Vologases' letter, Tacitus concludes his account on the Parthians in Annales. Of later events, he only mentions Tiridates' arrival in the capital of the Roman Empire in passing, without devoting much attention to it. He only states, in the context of his account of the trials of senators accused of actions hostile to Nero in $66 \mathrm{CE}$, that the presence of Tiridates was used to divert the attention of the citizens of Rome from these trials (Ann. 16,23,2).

What is striking in Annales is not just the extensiveness, but also the detail that Tacitus provides in his description of the events in Armenia and the war with Vologases. He not only meticulously presents the course of military actions, but also paints a detailed picture of the diplomatic contacts between the two sides, the ceremonial side of things, as well as the events taking place in the Parthian Empire itself. Tacitus' account is characterized by an impressive grasp of the succession of events and the links between them, as well as a concise narrative, in general lacking propaganda overtones; although he assesses and gives his opinion on the events, he does so with great restraint. Rather frequently, he places the events he describes in a specific geographical context. These virtues of his narrative suggest that he must have gleaned much of his information not only from archive documents, but also from the spoken and written reports of direct participants in the events. ${ }^{53} \mathrm{He}$ could only have gathered a complete picture of the events that took place in the East between 54 and $63 \mathrm{CE}$ in the memoirs of Gnaeus Domitius Corbulo, ${ }^{54}$ although he never clearly states that he made use of them. ${ }^{55}$

The subject matter of the surviving books of Historiae is mostly the course of the rivalry between the pretenders to the imperial purple in 68-69 CE. ${ }^{56}$ As a result, there are only few references to the Parthians. Those that can be found are generally concise interjections when Tacitus describes the events taking place on various fronts.

53 One such participant in the events might have been Marius Celsus, legate of legio XV Apollinaris, which he led during the war with Armenia under the command of Corbulo (Ann. 15,25,3; cf. Levick 2013, I: 543). He was the author of a work on the tactics of battle with the Parthians and a history of the civil war of 68-70 CE: Syme 1958, 297, 682-683.

54 For testimonia and fragments see Cornell 2013, II: 1030-1033. On contents and other problems related to this work, cf. Levick 2013, I: 541-545.

55 Cf. Syme 1958, 297; Levick 2013, I: 544-545.

56 Tacitus' surviving books show that he made use of the works of Roman authors, which were focused especially on the events played out in Rome and Italy. They were probably not interested in Parthian issues at all; cf. Syme 1958, 176-190. 
The first of these concerns the Parthians' engagement in supporting the usurper claiming to be Nero, who appeared in Asia Minor some time after the emperor's death (Hist. 1,2,1). ${ }^{57}$ Vologases supported him in the hope that the confusion the impostor caused in the Roman Empire would allow him to realize his own plans. Yet these hopes were dashed when the Roman authorities removed the usurper. Vologases' next opportunity came with the outbreak of civil war in the Roman Empire, shortly after Otho had been proclaimed emperor. From Tacitus' account, we only know that in spring $69 \mathrm{CE}$ unspecified actions were undertaken, with varying success, against the Parthians. ${ }^{58}$ Several months later, Vespasian, the commander of the Roman army in Judea, was proclaimed emperor. In order to be able to participate in the contest for the throne in Rome, he first needed to be sure that Syria, abandoned by the legions that supported him, would not be attacked by the Parthians. According to Tacitus, he protected himself against this eventuality by sending delegations to Vologases and Tiridates (Hist. 2,82,3). Hearing of the victory of Vespasian's forces in the battle of Bedriacum (24-25.10.69), Vologases offered him Parthian support in the form of 40,000 equestrian archers. Yet Vespasian rejected this offer, making it clear to the king's emissaries that the civil war in Rome was over (Hist. 4,51,1-2). In chronological terms, this is Tacitus' last direct reference to Roman-Parthian relations in the $1^{\text {st }}$ century CE.

As with the Annales, in the Historiae too Tacitus makes no mention of the source from which he got his information on the Parthians. We can only assume that, as in other cases, he made use of documents kept in archives, as well, perhaps, as Vespasian' journals, which along with a description of his military activity in Judea may also have contained information on the situation of the East after he was acclaimed emperor by the legions stationed in Egypt. ${ }^{59}$

$* * * * * *$

The description of the events that marked the shape of Roman-Parthian relations scattered throughout Tacitus' works suggests a certain random nature. Yet this is not the case. In the various elements of the narrative, the author refers to matters discussed earlier, creating a logical and chronological whole. He presents an extensive and very detailed description of events in Armenia and the East, with the Romans and Parthians as the main protagonists and the various peoples living there in secondary roles. This construction of Tacitus' account results from the convention of the annalistic narrative that he uses in his works. This requires some work from the reader to join the dots between the various episodes, but is very useful when it comes to determining the chronological sequence of events and the way they relate to each other.

One more feature of Tacitus' historical writing style is worthy of note. In his main historical narrative, when discussing Parthian issues, and especially Roman-Parthian re-

\footnotetext{
${ }^{57}$ Cf. Ann. 2,8,1-9,2; Suet., Nero 57,2.

${ }^{58}$ Hist. 2,6,1: (...) tantum adversus Parthos minae, vario eventu; (...); cf. Dąbrowa 1981.

${ }^{59}$ Cf. Syme 1958, 178.
} 
lations, he generally avoids any references, comparisons or assessments of the period outside of the chronological framework in question. His references to events that took place at other times are few and far between. They refer mostly to the period of the Republic: the expedition of Crassus (Germ. 37; Ann. 2,2,2), the battles waged with the Parthians by P. Ventidius Bassus (Germ. 37; Hist. 5,9,1), the expedition of Mark Antony (Hist. 2,2,2; 3,24,2), the results of his activity in Armenia (Ann. 2,3,1-2), and the accomplishments of Augustus (Ann. 2,1,2; 2,4,1; 12,11,1). Yet there is a lack of any allusions to the relations between the two states from his time, for example from the rule of Trajan or Hadrian.

We can assume that avoiding such allusions was intentional on Tacitus' part. The annalistic narrative style forced him to concentrate on the chronology of events of a strictly specified time frame. Anything outside of this infringed this concept, as inclusion of other contents distracted the reader's attention and took away from the necessary dramatic nature of the account. Besides, the few allusions mentioned above were generally made outside of the main narrative thrust, as interjections to the list of facts on the struggle for Armenia in the period before Tiberius' rule (Ann. 2,3,1-2,4,3), the history of legio III Gallica (Hist. 3,24,2), the history of Judea (Hist. 5,9,1), or as a comparison of the national characteristics of the Germanic tribes and Parthians (Germ. 37).

We have no reason to believe that the lack of more such references is proof that Tacitus lacked knowledge of other periods of Parthian history. The cited allusions to events from the time of the Republic show that he certainly had a good grasp of Roman-Parthian relations in that period too. We can assume that his knowledge of the history of the Parthians went well beyond the second half of the 1st century BCE. This is demonstrated by his reference to the Parthian activity during the era of Antiochus IV Epiphanes, which prevented the ruler from suppressing the Maccabean revolt (Hist. 5,8,2-3).

Yet Tacitus' knowledge of the Parthians was not limited to the history of their state and their rivalry with Rome over Armenia. On a number of occasions, he also shows a knowledge of their customs, social and political relations, state institutions, art of war, political ideology, etc. ${ }^{60}$ He no doubt gained a certain amount of knowledge by studying geographical and historical works by Greek and Roman authors, including Strabo ${ }^{61}$ and Pliny the Elder. ${ }^{62}$ The main source of Tacitus' knowledge, however, was probably - as suggested several times above - a work by an anonymous author written not later than in the second half of the first century CE. Even if the Roman historian was able to find a great deal of information on the internal affairs of the Parthian state in archive documents and the journals of Roman commanders, the detailed knowledge of events and the behavior of their participants that he exhibits makes it doubtful that these were his only sources. ${ }^{63}$ This is what suggests that he probably made use of some hitherto unidentified

60 Ehrhardt 1998, 298-302.

${ }^{61}$ Cf. Dąbrowa 2015.

62 Cf. Hackl et al. 2010, II, 307-313.

63 This information cannot have come from any of the works we know, whose authors discussed Parthian matters at great length or made them their main focus - they included Pompey Trogus, Strabo (whose work was on the geography of the Parthian state), Artemidorus of Artemita, and Isidore of Charax. Chronologically, these were in much earlier times. At best, the narrative of some of them ended in the era of Augustus or the first years of Tiberius' rule. 
work written by an author with a very good knowledge of Parthian realities. This extensive understanding of issues connected with various aspects of the Parthian state and its politics means that we can assume that this anonymous author was probably not of Roman origins. ${ }^{64}$ As Tacitus makes no reference to his sources, this hypothesis, though, very attractive, is difficult to verify.

It is notable to that Tacitus avoids any commentaries of an ethnological nature on the Parthians. ${ }^{65}$ The observations on Parthian customs that appear from time to time are mostly used to illustrate the factors determining their social behavior. ${ }^{66}$

An important characteristic of Tacitus' work is the perception of the Parthians as a worthy rival of Rome. Although he does not eschew negative assessments and opinions in this matter, ${ }^{67}$ Tacitus avoids solely presenting the Roman point of view in his version of events, instead trying to show the reasons for the actions of the adversary. A certain conviction of the civilizational superiority of Rome is evident in his assessments, but this does not diminish the value of the picture of the Parthians and their political activity in the 1st century CE that he paints. This picture is exceptional in being one of the fullest that we have, not only of this period, but also of the whole of Roman historiography. We should remember, though, that Tacitus was certainly not motivated by the intention of presenting a complete history of the Parthians and the structure of their state to the Roman reader. He always looked at everything concerning the Eastern neighbor from a Roman perspective, through the prism of the Roman-Parthian rivalry for influence in Armenia and domination in the East.

One of the possible reasons for which Tacitus devoted so much space and attention to the Parthians in his works might have been a desire to mitigate the unfavorable impression given by the failure of Trajan's expedition against the Parthians and Hadrian's Parthian policy. ${ }^{68}$ By portraying a broad panorama of the difficult struggles with the Arsacids faced by previous rulers of Rome, he might have been hoping to persuade his readers that both emperors had done everything they could to protect Roman interests, even if the ultimate result of their endeavors was somewhat lacking. ${ }^{69}$

${ }^{64}$ He certainly was not Josephus. Although his Antiquitates and Bellum Judaicum contains many lengthy passages on Parthian issues in the $1^{\text {st }}$ century CE (cf. $A J 18,39-52$; 96-104; 325-339; 353-357; 371-379; $20,54-74 ; 81-93 ; B J 7,220-242 ; 244-251)$, his account varies in many important details from that given by Tacitus. For this reason, we can probably rule out the possibility that Tacitus knew and made use in his narrative of Josephus' works. On the other hand, Josephus' good grasp of the political and social history of the Parthians, evident in his Antiquitates, might suggest that he too owed it to a source that is not widely known whose author gave much attention not only to the history of the Parthians but also to the fate of the Jews in their state; cf. Täubler 1904; Colpe 1974, 97-108; Goodblatt 1987, 605-622; Rajak 1998, 315-323.

65 Cf. Walser 1951, 72-74.

${ }^{66}$ Cf. Ann. 2,2,1-4; 6,43,3.

67 The source of Tacitus' critical opinions and assessments of the Parthians is his perception of them as barbarians not always capable of appreciating and accepting the benevolence of Roman culture and the associated values system, and given to conduct not in keeping with the principles to which the Romans adhered; cf. Ann. 2,2,1-4; 6,32,1; 12,11,2; 12,12,2; 12,14,3; 13,38,2. See also Walser 1951, 67-72; Ehrhardt $1998,304$.

${ }^{68}$ Cf. Potter 1991, 290; Birley 2000, 242.

${ }^{69}$ I would like to thank Dr. S.J.V. Malloch for valuable comments to preliminary draft of this paper. Any error of fact or interpretation is solely responsibility of the author. 


\section{ABBREVIATIONS}

PIR $^{2}$ - E. Groag, A. Stein et al., Prosopographia Imperii Romani saec. I, II, III, editio altera, Berlin 1933-2015

RPC - A. Burnett, M. Amandry, O.P. Ripollès, Roman Provincial Coinage, vol. I : From the Death of Caesar to the Death of Vitellius (44 BC-AD 69), London - Paris 1992

\section{BIBLIOGRAPHY}

Birley, A.R. (2000), The Life and Death of Cornelius Tacitus, Historia 49: 230-247.

Colpe, C. (1974), Die Arsakiden bei Josephus, in: O. Betz, K. Haacker, M. Hengel (hrsg.), JosephusStudien. Untersuchungen zu Josephus, dem antiken Judentum und dem Neuen Testament. Otto Michel zum 70.Gebutrstag gewidmet, Göttingen: 97-108.

Cornell, T.J. (ed.) (2013), The Fragments of the Roman Historians, vol. 2: Texts and Translations, Oxford.

Dąbrowa, E. (1981), Les rapports entre Rome et les Parthes sous Vespasien, Syria 58: 187-204.

Dąbrowa, E. (1983), La politique de l'État parthe à l'égard de Rome-d'Artaban II à Vologèse I (ca 11-ca 79 de n.e.) et les facteurs qui la conditionnaient, Kraków.

Dąbrowa, E. (1984), Vologèse I et l'Hyrcanie, Iranica Antiqua 19: 141-147.

Dąbrowa, E. (1987), Les premiers 'otages' parthes à Rome, Folia Orientalia 24: 63-71.

Dąbrowa, E. (1989), Les héros de luttes politiques dans l'État parthe dans la première moitié du I ${ }^{\mathrm{er}}$ siècle de notre ère, Iranica Antiqua 24: 311-322.

Dąbrowa, E. (1994), The Bellum Commagenicum and the ornamenta triumphalia of M. Ulpius Traianus, in: E. Dąbrowa (ed.), The Roman Army in the East. Proceedings of a Colloquium held at the Jagiellonian University, Kraków in September 1992, Kraków: 19-27.

Dąbrowa, E. (2002), '... ostentasse Romana arma satis ...'. The Military Factor in Roman-Parthian Relations under Augustus and Tiberius, in: Ph. Freeman et al. (eds), Limes XVIII. Proceedings of the XVIII $I^{\mathrm{t}}$ International Congress of Roman Frontier Studies held in Amman, Jordan (September 2000), Oxford: 275-279.

Dąbrowa, E. (2013), The Parthian Aristocracy: Its Social Position and Political Activity, Parthica 15: 53-62.

Dąbrowa, E. (2015), L'histoire des Parthes dans la Géographie de Strabon, Studi Ellenistici, vol. 29, Pisa-Roma: 285-303.

Debevoise, N.C. (1938), A Political History of Parthia, Chicago, IL.

Eck, W., Caballos, A., Fernández, F. (1996), Das senatus consultum de Cn. Pisone patre, München.

Ehrhardt, N. (1998), Parther und parthische Geschichte bei Tacitus, in: J. Wiesehöfer (hrsg.), Das Partherreich und seine Zeugnisse. Beiträge des Internationalen Colloquiums, Eutin (27.-30. Juni 1996), Stuttgart: 295-307.

Goodblatt, D. (1987), Josephus on Parthian Babylonia (Antiquities XVIII, 310-379), Journal of the American Oriental Society 107: 605-622.

Hackl, U., Jacobs, B., Weber, D. (2010), Quellen zur Geschichte des Partherreiches. Textsammlung mit Übersetzungen und Kommentaren, vol. 2, Göttingen-Oakville, CT.

Heil, M. (1997), Die orientalische Außenpolitik des Kaisers Nero, München. 
Karras-Klapproth, M. (1988), Prosopographische Studien zur Geschichte des Partherreiches auf der Grundlage antiker literarischer Überlieferung, Bonn.

Kovacs, F.L. (2014), Artaxias III and a Numismatic Enigma, Armenian Numismatic Journal, ser. II, 10: $19-25$.

Kovacs, F.L. (2016), Armenian Coinage in the Classical Period, Lancaster, PA-London.

Krengel, E. (2013), Die erste Münzprägung für Zenon / Artaxias aus Pontus, JNG 63: 59-73.

Levick, B. (2013), 82. Cn. Domitius Corbulo, in: T.J. Cornell (ed.), The Fragments of the Roman Historians, vol. 1: Introduction, Oxford: 538-545.

Malloch, S.J.V. (2013), The Annals of Tacitus, Book 11. Edited with a Commentary by S.J.V. Malloch, Cambridge.

Niedergaard, E. (1988), The Four Sons of Phraates IV in Rome, Acta Hyperborea 1: 102-115.

Oliver, R.P. (1977), The Praenomen of Tacitus, AJPh 98: 64-70.

Pani, M. (1972), Roma e i re d'Oriente da Augusto a Tiberio (Cappadocia, Armenia, Media Atropatene), Bari.

Pani, M. (1993), La missione di Germanico in Oriente: politica estera e politica interna, in: M. Pani, Potere e valori a Roma fra Augusto e Traiano, $2^{\text {nd }}$ ed., Bari: 235-255.

Potter, D.S. (1991), The Inscriptions on the Bronze Herakles from Mesene: Vologeses IV's War with Rome and the Date of Tacitus' Annales, ZPE 88: 277-290.

Rajak, T. (1998), The Parthians in Josephus, in: J. Wiesehöfer (hrsg.), Das Partherreich und seine Zeugnisse. Beiträge des Internationalen Colloquiums, Eutin (27.-30. Juni 1996), Stuttgart: 309-324.

Scardigli, B. (2009), Ostaggi - 'ospiti' a Roma, in: S. Conti, B. Scardigli (a cura di), Stranieri a Roma. Atti del Convegno Internazionale di Studi (Certosa di Pontignano, 22-23 maggio 2006), Ancona: 121-143.

Shayegan, M.R. (2017), Persianism: or Achaemenid Reminiscences in the Iranian and Iranicate World(s) of Antiquity, in: R. Strootman, M.J. Versluys (eds.), Persianism in Antiquity, Stuttgart: 401-455.

Sonnabend, H. (1986), Fremdenbild und Politik. Vorstellungen der Römer von Ägypten und dem Partherreich in der späten Republik und frühen Kaiserzeit, Frankfurt a/M-Bern-New York.

Strugnell, E. (2008), Thea Musa, Roman Queen of Parthia, Iranica Antiqua 43: 275-298.

Syme, R. (1958), Tacitus, 2 vols., Oxford.

Täubler, E. (1904), Die Parthernachrichten bei Josephus, Berlin.

Walser, G. (1951), Rom, das Reich und die fremden Völker in der Geschichtsschreibung der frühen Kaiserzeit. Studien zur Glaubwürdigkeit des Tacitus, Baden-Baden.

Wheeler, E.L. (2002), Roman Treaties with Parthia: Völkerrecht or Power Politics?, in: Ph. Freeman et al. (eds.), Limes XVIII. Proceedings of the XVIII ${ }^{\mathrm{h}}$ International Congress of Roman Frontier Studies held in Amman, Jordan (September 2000), Oxford: 287-292.

Wolski, J. (1966), Les Achéménides et les Arsacides. Contribution à l'histoire de la formation des traditions iraniennes, Syria 43: 65-89.

Wolski, J. (1991), L'époque parthe entre l'hellénisme et l'iranisme, in: Histoire et cultes de l'Asie Centrale préislamique : sources écrites et documents archéologiques. Actes du Colloque international du CNRS (Paris, 22-28 novembre 1988), Paris: 49-55.

Wolski, J. (1993), L'Empire des Arsacides, Leuven. 